\title{
EVALUATION OF PROGRAM BORDER MANAGEMENT TO KEEP SOVEREIGN NATION THE NORTH KALIMANTAN \\ (Regional leadership Based on Transformational Leadership and lokal wisdom)
}

\author{
Dicky Wainal Usman,* Djaali,**Madhakomala,*** \\ State University of Jakarta** \\ usmandickywainal@gmail.com* \\ djaali@unj.ac.id \\ r.madhakomala@unj.ac.id
}

\begin{abstract}
This research aimed to evaluate on five (5) steps;: (1) design of Border Management, (2) installation for Border Management,(3) process of Border Management, (4) product of Border Management, and cost / benefit for Border Management, for keep sovereignNation on North Kalimantan, This research is the programme evaluation research use Discrepancy Evaluation Model (DEM), data collection techniques are using; interview, observation, documentation and questionnaire for analyzer discussion support. Analysis of the data use Raph Tylor model as follows data reduction, data display and verification as conclusion.Results of this research include: (1) draft design, (2) border management plan, (3) compile of policy strategy with the help of stakeholders and HR agencies (4) the process of planning, organizing, staffing, directing, coordinating, reporting and budgeting for border management, and (5)lack of budget management.Besides is non-functioning of transformational leadership and effective local wisdom on North Kalimantan
\end{abstract}

Keywords: Program Evaluation, Border Management, Regional Leadership, Transformational Leadership, Local Wisdom, Discrepancy Evaluation Model (DEM)

The local culture as the foundation of local wisdom, is the basic philosophical of an organization sociology, which form the basis of the value that is used as norm in the local community where the norms of guiding the behavior of members, and can provide recognition status to every individual, and the norm is the rule in formal and non formal to develop its region, including in the provinces of NorthKalimantan, so the local culture into local wisdom as a base on future live of society. In connection with this evaluation is needed to improve how the Government policy in border management program, implementing strategies Transformational leadership, strengthening local culture, and discrepancy occurring in border management in the province of North Kalimantan, In an effort to defend the sovereignty of the Republic of Indonesia.

Suitability evaluation model of regional discrepancies based policies that transformational leadership with their local wisdom, intended to improve, enhance and modify the border management program and in an effort to raise public awareness of the border, so the border management program in maintaining national sovereignty can be realized. Worthen and Sanders (2005: 32) The evaluation is an activity to find something valuable about something, in search of something that also includes looking for information useful in assessing the existence of a program, production, procedure and alternatives strategies proposed to achieve the objectives management defined borders. Stufflebeam (2000: 4) defines evaluation as the imaging process, searching for and providing useful information for decision makers in determining the decision alternatives. Anderson (in Arikunto) considers evaluation as a process of 
determining the results achieved several activities planned to promote the goals. Tufo (200: 71) Evaluation is a systematic determination of a subject's worth and significance, using criteria governed standards. Vendung, (2009: 2) evaluation is the process of determaining the skelter, worth and value of thing. Viviane and Gilbert (2000: 39.) that evaluation is the process of determining whether the implementation of activities in accordance with the expected goals.

Alkin in Wirawan (2004: 34) Evaluation is the process of ascertaining the decision areas of concern, selecting Appropriate information, and collecting and analyzing information in order to report summary data is useful to decision makers in selecting Among alternative. Aiken (2004: 34). Evaluation aims to obtain feedback on the activities that have been implemented, as the information to carry out the following activities. Vendung, (2009: 2) evaluation is the process of determaining the skelter, worth and value of thing. Scriven (2009: 1-2) the traditional definition of evalution involves judging the merit or worth of some for example, a program, a policy, or product. Viviane and Gilbert (2000: 39) the process of determining whether the implementation of activities in accordance with the expected goals.a special program is a specific plan of organization for a specific purpose (2001: 241). Widoyoko (2009: 17) The process of setting the decision was based on a comparison carefully against the observed data by using specific standards that have been standardized. Tayipnapis (008: 62) The evaluation is tantamount to supervision activities. Pearson (2002: 311) Evaluation associated with research focuses on five stages, namely stages: 1) design (Design, 2) Setup / installation (installation,) 3) Process (Process), 4) Product (Product), and 5) cost / impack (cost), Ford (2001: 245) what, who, how. What, who and how. Phillip (2000: 182-185)

Goal free of Michael Scriven, Evaluation Measure all policy effects of the activity or project, 2) adversary, Thomas Owen, the pros and cons of activity, pro only collect data on all the positive things: success, positive benefits, efficiency, effectiveness of activities and cons; only collects information about the failure, ineffectiveness and inefficiency of activities, 3) formative and summative evaluation, 4) CIPP, 5) responsive evaluation, 6) goal-based evaluation, 7) black box evaluation, 8) Evaluation System, 9) analysis system , 10) connoisseurship evaluation, 11) evaluation gap (discrepancy), 12) the Delphi technique, 13) Policy evaluation Decisions, 14). and others. Stake, which emphasizes the two basic activities, namely the evaluation of Stake (2011: 119-123) Descriptions and Judgement, and distinguishes three stages in the education program, namely Antecendents (Context), Transaction (Procces), and Outcomes (Output). Davidson (2011: 422-425) antecedents, Transaction, Outcomes, Manpower. Delanty (2006: 3) Some of these components are key to understanding the context of the border region. Andrew, P. and Snyder, T (eds.). 2000: 8) The concept of the lead to a better control on the movement of workers, refugees and terrorists. Crossings (2005: 74) The development of the border is seen as a matter of urgency, it is seen from the magnitude of the gap between rich and poor countries that lead to conditions of stability and security. Scheneier (1987: 4) Security is the degree of resistance to, or protection from, harm. It Applies to any vulnerable and valuable asset, such as a person, dwelling, community, nation, or organization ".

So the description refers to the application of supervision in the field in the frontier area is defined as a program evaluation, validation may be same interpreted with BPPD institutions in accepting BNPP as Chairman of border management. Evaluation of the program is the first step of the process of accreditation and validation agencies. The government's policy on the implementation of border management program in the province of North Kalimantan covers How Government Policy in border 
management in the province of North Kalimantan ? How does cooperation in border management strategy in the province of North Kalimantan? How strategy Strengthening attitudes behaviors of society and efforts made to achieve Indonesian Republik sovereignty?. How to create safety in the border region of North Kalimantan Province ? and how does impact the results of border management in the province of North Kalimantan?

\section{METHOD}

The approach used in this study is a qualitative approach using descriptive methods to review the program gaps. Research methods used in the study was descriptive qualitative method. Descriptive qualitative methods performed to evaluate gaps North Kalimantan border management program as planned compared to the reality on the ground. Evaluation Model "Discrepancy" gaps introduced by Provus in Nyre \& Rose, which is a model that emphasizes the importance of policy evaluation before comprehension evaluation system.

\section{Design border management policy in North Kalimantan}

Local community prefers the life of the State neighbour (Malaysia), they preferred staple goods, oils, medicines originating from Malaysia, so that the rate of criminality, including drug smuggling is difficult to overcome. People are less concerned about a sense of nationalism, patriotism, defense of State, and build a life in the container NKRI, they often say in my chest is Pancasila, but my stomach is Malaysia. The number of people who have dual citizenship because they need a job from Malaysia, due to lack of jobs, while the daily life of those in Indonesia. Local leaders today are growing still transactional every official has a duty and responsibility to be resolved and the liabilities, claims the head of the area to his subordinates to complete each task, where the head of the region is less motivating, models, and approaches to subordinates, a officials supposed to understand, capable and can run errands. In the development did not become common knowledge gets a certain percentage of local governments in governance of each assistant, project leader and head of the division and performed a transactional basis. While the leadership of the new transformational character discourse and generally at the level of head of the division, and assistant bureau chief less understand the principles, nature, principles and application of transformational leadership

\section{Instalation, cooperation in border management strategy in the province of North Kalimantan}

Cooperation between border guards and managers can not run in the same manner as expected, in and responsibilities are clearly in line with the weight of responsibility that has been measured by each institution, the next problem is the need for cooperation between functions is not just a task together.accordance with the duties and functions or each still walk on their own, there is no alignment, so that their synergies can not be measured. This happens because the leadership of the manager who handled by local governments are lacking in implementing the vision and mission of border management can not be internalized by the officers and border guards, and the presence of a manager in the border region is very less considering the flurry of local officials and personnel assigned to handle and oversee the management of border not being able to interact, communicate and be a good partner. Operational activities of officers, border guards and the manager still runs itself alone, their duties and their respective functions and preoccupations overcome the problems of each, especially the problem of accommodation and transport. Lack of transport facilities and support clean water and other facilities needed to support 
the implementation of the tasks. In the area of authority and responsibility respectively, have own job description duties

The software has been no cooperation, need to be built SOP begins with making the fixed procedure of each function and then created a unified standard operating procedure, and then do the training each function measured manner. SOP to build reliable and capable of operating in the management of border efforts are needed to improve local leadership using transformational leadership, if only rely on leadership as it is now estimated SOP will never materialize.

\section{Process, Strategies Strengthening attitudes behaviors of society and efforts made to achieve sovereignty Republic of Indonesia}

Strengthening of attitudes and behavior carried through the development of local culture, local knowledge and implementation guidance in the form of defending of Country counseling, patriotic country, a growing sense of nationalism is often perpetrated by the territorial and local Government through counseling and guidance to the public, but the results can not be expected remember people always compare the condition of the border with the state of his brothers in Malaysia lives far better than life in the territory of the Republic of Indonesia. Besides, they also always give a sense of obligation and duty of the community in helping to border management, towards a better society, fair, prosperous and dignified, yet again because too many unfulfilled wishes of the people at the border, they are less response than supporting development the border, they are more intense in activities which destroy nature, smuggling of various commodities, including drugs either through the territorial sea and rivers and land area.

Strengthening the local culture and local wisdom routinely are conducted continuously by the department of social Goverment Kaltara area, but the results can not bring people who have local knowledge which is able to be coupled with national wisdom. Beside their life that lack, lack of roads and facilities and transport facilities they have, so they are always comparing with infrastructure Malaysian territory as well as the number of arrivals making disappointment in themselves, because they underappreciate the social life within the Unitary State of the Republic Indonesia.

Community empowerment through regulations or rules to build housing facilities. Facilities and infrastructures, roads and transport facilities and infrastructure of adequate accommodation in a life, they have been raised in a safety container of spontaneous community still pros and cons, especially to move people and villages that were near the border, particularly those who have dual citizenship. Through education, early warning system (detection and early sensory) verily they would be people who are very helpful security on the border with the application of rules or regulations effectively.

The security stakes performed by border patrols routinely Satgaspamtas task forces and joint patrols with the royal army of Malaysia, including the assignment of a special team of Jakarta in order to improve border stakes. Currently under construction road parallel stakes limit along 1,038 km to the border with West Kalimantan by units of Engineers of the Army, but the result was only $30 \%$ for 2 years running, is expected in 2020 , roads have been able to be used as a road patrol at once the way to controlling the border region.

Implementation of border diplomacy conducted by the Indonesian National Army and local governments, related diplomacy territory by local governments Kaltara, invites Mulawarman University as partners working diplomacy and in fact elements of the university often complained about the lack of 
professionalism of the team members diplomacy of local government Kaltara and parties Malaysia which always fetched, inconsistent and often throw tantrums, resulting in less effective diplomacy, is not able to be applied in the field. Diplomacy Indonesian Armed Forces with Malaysian soldiers can run and consequently the results can be applied in the field, if there are problems can be discussed and resolved together.

\section{Products, creation of security in the border region of North Kalimantan Province}

for managing insecurity in the mainland need additional personnel Satgaspamtas of the present conditions that as a duty 2 Satgas plus 1 to 3 Satgas task force with force personnel have eambanment 1.050 parsonnel this from long distance calculation border $1.038 \mathrm{~km}$ until 1 Satgas personnel able to monitor $1 \mathrm{~km}$, this ratio much better if just than ratio long standing. Beside assignment was strengt hembankment TNI personnel will upgrade intense reaction speed at the time of inter-ethnic unrest often occur border region, given the limited police personnel in the border region, whereas inter-ethnic fray this very negative impact on the creation of ordeliness security and society and a harmonious life within the unitary state of Indonesia.

To address the vulnerability in the presence of sea ship speed boats and patrol boats at any time across the Amballat waters and sea borders of the Republic of Indonesia and Malaysia as often happens entry of foreign vessels mainly Malaysia to the sea area of the Republic of Indonesia . Where it is necessary to tools special tools detection and prevent premature placed in the post heading the naval especially in area prone to smuggling and the entry of foreign fishermen to the sea area of the Republic of Indonesia as well as the organization of the navy had had Headquarter and therefore the need empowerment and the addition of equipment and weapon system sea in order more increase quality execution of tasks and attendance at sea. to overcome air reconnaissance mainly done by planes, Indonesia has time to develop a fighter aircraft of Madiun or Makassar routed to Tarakan Air Force base in view of the results of observations made by researchers using radar on Satrad AU Tarakan indicates that when there is no fighter which stand bay in Tarakan Air Force base then the territorial violations will occur, otherwise when in the stand by aircraft airfield Tarakan accommodation airspace violations do not occur. Therefore necessary force fighter squadrons stationed in Tarakan Air Force base.

Improved security guard border areas, especially border areas needs something to do with the construction of accommodation facilities more humon forArmy troops their considering difficult places in the hill country and the lack of clean water media that requires infrastructure better accommodation than when this Satgaspamtas and army troops in the border areas to individual facilities need to be equipped with better tools support equipment and tools, vehicles and weapon system accordance with the duties and functions of each. Isolation of the border need to be opened and constructed in accordance with the paradigm of the border as the forefront of the Unitary Republic of Indonesia

\section{Cost, Impact of the results management in the border region of North Kalimantan Province}

Management of border areas has not been implemented optimally legal basis should be revised improvement, the presence of local government as a manager needs to be revisited because his presence can not be optimal, and his leadership was not able to build the vision and mission of managing the border effectively and reliably the impact is felt directly by the officers and border guards often be hesitation and lack of compliance because the command run by the region can not follow thythm life of border management, which is essentially a large part management defense and National security unity, inter-ethnic frequent commotion caused by the attitude of many people jealous of outsiders who continually develop land ownership and land for subsistence migrants. many Indonesian workers 
especially those illegally deported from Malaysia did not return home but settled in the border region is particularly the case in Nunukan. Local communities there often to protect against the presence of immigrants often inter-ethnic unrest highly damaging national unity Kaltara Indonesia in the region, especially the educated elite, especially those who often provoke people to local communities about the settlers.

lack of community care occurred protection of the border region as a result of the lack of empowerment of the results of the management of Natural Resources, during which only benefit the investor. Society lives amid Natural Resources were quite good and the potential, but does not enjoy the results as expected on the territory of the region which has a good Natural Resources. investors in the border region many invest their shares in oil palm plantations and the average in the border region inevestor from Malaysia they are more concerned with corporate profits than to help and solve the difficulties of society so that people who are isolated and they are still living with the move (nomadic) received less attention and assistance from the government and investors so that they become indifferent, decrease care about the environment and many of those who are forest dwellers (illegal logging) and damage the environment due to the nomadic life. Community empowerment through belts-seat belts is one of the solutions in order to increase the participation and passion for the environment and helps to border management.

Security vulnerability in the region-region, village dwelling place of the community as a result of drug smuggling and community needs as well as environmental destruction and illegal logging is done by the community adjacent to the border line. Rampant drug trafficking from Malaysia through the waters and land, into the rivers and up in the villages, so many community leaders who complained about drug trafficking like hotcakes, it causes destruction of young generation in the border region mainly due to drug consumption and more isolated from the community to be very backward and less accommodative and participative lives on rural development and improving the quality of education in society

\section{DISCUSSION}

\section{a. Discussion on Design}

BNPP establishment as a representative of which is the existence of the draft border management in maintaining the sovereignty of the country from internal and external threats, which plays a role in setting policy strategy, work programs, budgeting and management of goal attainment standards. In general, border management plan refers to the design concept of management (management), which consists of a variety of design functions; planning, organizing, mobilizing, coordinating, reporting, budgeting and control, and all of it in the implementation of managerial, to draft a strategy in accordance with the standards of achievement of management objectives, the main target of a particular organization management.Many sources of the concept of management or management, such as Planning, Organizing, Actuiting and Controlling (POAC), Planning, Directing, Check and Action (PDCA), Planning, TERIFIC, Leading, and Controlling (POLC), and others, but which very relevant in this study is the Planning, organizing, staffing, Directing, Coordinating, Reproting and Baudgeting better known by the name of POSDCoRB, which perform the functions of management or management by implementing of planning (plannnig), organizing (organizing), Mobilization (Directing), coordination (Corordinting), reporting (reporting) and budget (budgeting), however most appropriate for the management of the border is 
POSDCoRB (planning, organizing, staffing, directing, coordinating, reporing and budgeting), all highly relevant to the activities of border management

1. Establishment of design in shaping relations activities and the limitation of authority and accountability and border guard officers from various agencies, so that border management is required to create a work environment conducive to a healthy and dynamic cordination and set up a joint agreement on a work assignment in achieving successful management of the border using the reporting system as a source of information in accordance with the duty manager responsibilities

2. Determination of the source of funds and budgeted costs for the design of border management, to supporting the development of pure ideas as local wisdom that extends from socialized by way of empowerment of people's lives, build a seatbelt in exploring potential areas of North Kalimantan province. Thus the core of the design steps in border management BNPP DEM is as representative prepare draft management as well and as accurately as possible, utilizing the available budget with the involvement and empowerment of local communities optimally.

Thus the core of the design steps in border management BNPP DEM is as representative prepare draft management as well and as accurately as possible, utilizing the available budget with the involvement and empowerment of local communities optimally.

\section{b. Discussion installations}

1. Leadership, in doing construction to move the recruitment, coordination and reporting of recruitment officers from various agencies to perform tasks together in a working structure based SOP areas of expertise in order to create a conducive working environment, healthy and dynamic, so the need to set a deal together on a work assignment in achieving success in integrated persisten procedure, which is supported by the resources according to the task of border management responsibilities.

2. The scope of management, budgeting, public management of the natural environment based on the vision and mission, the priority agenda of policy direction, and the rules of border management, including (5) related matters, namely; 1. Condition of the State Border, 2.issues of strategy, 3. basic principles of vision and mission, 4. Agenda priority policy direction, and 5. The rules of border management by involving the community in and set a budget of resources and costs are distributed to border management, as well as their awareness of the environment involved in border management.

The room spacious enough with the environment management activities based on the management of budgets that have been set, but it needs to participate preservation of nature with a clear vision and mission, as prescribed by law, with attention;

a), the condition states borders, which is a requirement known or circumstances that exist in the field and around the border. Field conditions along the border was to be understood by managers, the goal is to make it easier for officers and border guards carry out operations,

b) issue as an unsolved problem and are ready to take its decision, represents a gap between management practices in the field hoping to solve some of the vulnerabilities of security, while the strategy is an overall approach with regard to the implementation of the idea, planning, and execution of an activity within certain times during the legislation applicable or valid, thus the issue of the strategy is a condition or thing to be aware or in prioritizing the development planning for the impact will be 
significant to the entity (local / community), especially on the border in the future, poured through SOP covering ; a) The system of regeneration; b) the organization's management system; c) the strengthening of the economic rights of the people; and d) the source of funds remains Ease; e). the basic principles of border vision and mission is aligned with the vision and mission considerations both at the level nationalism up at the regional level focused on the development of nationalism and sovereignty of the territory; f). Agenda priorities are all areas the policy direction should hold the optimization of financial conditions that must be adapted to the policy of the Central Government, and finally g). border management rules as the rules that organize the behavior of managers in public life.

3. Recruitment, strategy mechanism, supporting facilities and services that a strategy needs careful attitude towards the violation of Indonesia and remain vigilant of all threats to the sovereignty of States side of the border, mainly address the vulnerability on ground with the addition of border posts and the addition of personnel Satgaspamtas, make proposals patrol boats, and ship fast, and the proposed construction of the air squadron at the air base Tarakan, by continuing to strive meningkatkann develop the quantity and quality of facilities necessary to support the needs of the service manager to obtain, simplicity, attention to perform tasks of border management.Thus the core of the installation steps in the DEM is structuring regularly to border management BPPD as representative BNPP to organize a systematic management as possible, based on the design of the design is to do the design of management functions to carry out the design of planning, design organization, design Mobilization, design coordination, the draft report and the budget, however, is most appropriate for the implementation of border management is POSDCoRB (planning, organizing, staffing, directing, coordinating, reporting and budgeting).

\section{Process Discussion}

Realization of management, has a real action in achieving successful management of border showed positive results, according to the planning of the support staff, to be directed, through the coordination of a structured set in SOP and PROTAP integrated in order to achieve unanimity and solidarity of work and report information accountability to state and included in allocating funds for the budget.Management process embodied in the SOP that, in principle, in accordance with the design of the design, which is then installed according to the rules Emitter management process significantly. Based on the design and installation according to the management concept POSDCoRB, namely carrying out or planning process, organising, supportive, directives from the leadership of border management, coordinating structured to obtain togetherness work to all members of border management, accompanied by the allocation of funds in accordance with the government's ability, reinforced with reports of members of officers and border guards that becomes an integrated border management report to the State and the nation.In the process of border management are also gaps (discrepancies), especially on field officer, Tim of LGs do not understand the condition of the field, so just accept statements only, while the greatest role is like a border guard official border crossings TNI and Officer.

1. Leadership tranformational has a vision for the future devote its concern for the problems faced by his subordinates and personal development of each of his followers, in the components of idealized influence, inspiration motivation, Intellectual stimulation and individualized consideration, so that the

necessary leadership to create a working atmosphere conducive, as given individual oriented ability to lead it.

2. In the Regional Kaltara not growing consciousness of public participation in the potential of the natural environment, so as to ensure the preservation of nature and emphasis on empowering 
accompanied by maintaining the culture workshops! which became local wisdom as the habits of the people to keep the potential of a! am to meet life resources.

3. The involvement of relevant agencies to meet the needs of stakeholders as members of the management, to assist in the task of border management, which has the quality of competence in accordance with his expertise, to sustain the needs of border management.

4. HR stakeholders selecting various relevant agencies of the military, local government, police, and customs according to their expertise, to assist border management.

Thus the core of the process steps in the DEM is implementing border management BPPD as representative BNPP take real action in achieving successful management of borders by POSDCoRB, with the involvement of the military, local government, police, and customs to stimulate public participation in the preservation of nature and local wisdom involves relevant stakeholders in helping management areaborder. Besides the leadership transformtional Things regional leadershipdiscouse still in early stages and have not been able realism in line with expectations.

\section{d. Product discussion}

Results management in maintaining the sovereignty of the state and nation, so, conclusion of the study is the success of border management in defending the sovereignty of the state and the nation, security and stability are supported by professional human resources in accordance with their competence and professional expertise in performing their duties and operations in border areas Kaltara, achieved despite not optimal. The achievements management has run the task as much as possible to maintain the sovereignty of the country, although there are still many deficiency facilities, adequate equipment, the team are still overlapping, sometimes even co-ordination less compact, which terkdang between officials of the other officers each other out of sync, with a limited budget, and therefore the results of border management has not achieved optimally. The result of the leadership of the region teransformational Kaltara that the attitude of community members in building and supporting local leadership is lacking in implementing community development in Kaltara.

\section{e. Impact discussion}

The impact of border managementbased on DEM, withthere is limitedness budgetmake many difficultywithinbudgetovercome for scant disturbed, purchasewith adequate equipment, tool, utility, and withweak area leadershipwithinrealizeexpectation development, andincreasingly weakbecousenot formed local wisdom, which not to be mixedwith national culture, andoften occurconflictwhich excessiveto created The Unitary State of the Republic of Indonesiawhith secure, peaceful, safe and prosperous.

In accordance with overall research outcome DEM concerning design, instalation, proses, product dan cost / Impact border managementthat although border management lack of budget, but still to perform the task properly, which support by task force from several competent institution, have a lot of discrepancy which extreme striking, particularly, not found to overcome disturbed inside in long time frame, weakness at the field official. Transformational leadership recent inside in expression level and concerning influence to border management is not significance, beside that local wisdom can't follow aktive participate to prop up border management.

\section{B.Discussions}


Based on the results of questionnaires as the data supporting the added value of research is important for reinforcing the argument that served as regional head of transformational leadership is not significant, are as follows:

Recapitulation of the results obtained from the following data:

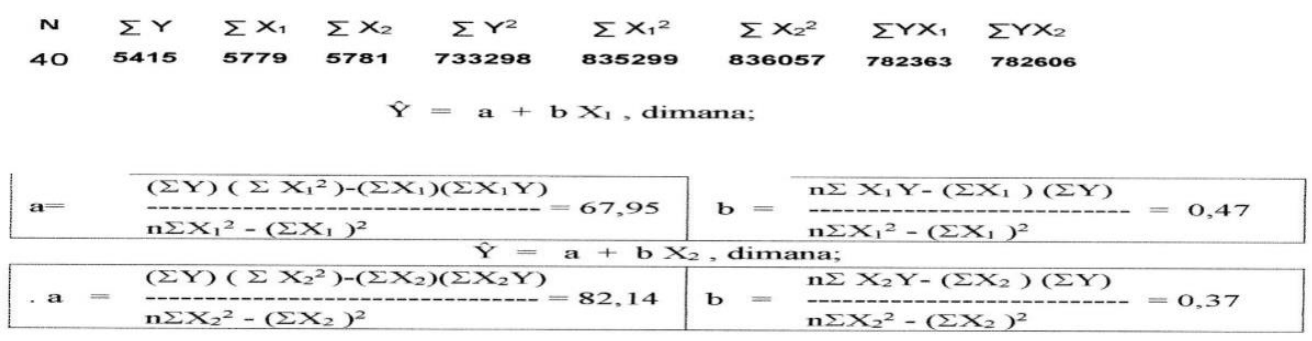

4.9 Anova table calculation based on data from research on the impact of transformational leadership terhadpa research management

\begin{tabular}{|c|c|c|c|c|}
\hline \multicolumn{2}{|c|}{ Yatas $X_{1}$} & Pers. Regressi & \multicolumn{2}{|c|}{$\hat{\mathrm{Y}}=67,948+0,468 \quad \mathrm{X}_{1}$} \\
\hline No & Uraian & Rumus & Perhitungan & Hasil \\
\hline 1 & $J \mathrm{~K}_{\text {Total }}$ & $\mathrm{JK}_{\text {Total }}=\sum \mathrm{Y}^{2}$ & Data penelitian $\sum \mathrm{Y}^{2}$ & 733298 \\
\hline 2 & $\mathrm{JK}_{(\mathrm{a})}$ & $J K_{(a)}=(\Sigma \bar{Y})^{2} / n$ & $\mathrm{JK}_{(\mathrm{a})}=5415^{2} / 40$ & 733055.6 \\
\hline 3 & $\mathrm{RJK}_{(\mathrm{a})}$ & $\mathrm{RJK}_{\mathrm{a}}=J \mathrm{~K}_{(\mathrm{a})} / \mathrm{db}_{\mathrm{a}}, \mathrm{db}_{\mathrm{a}}=1$ & $\mathrm{RJK}_{\mathrm{a}}=733055,6$ & 733055,6 \\
\hline 4 & $\mathrm{JK}_{(\mathrm{reg})}$ & $\begin{array}{c}\mathrm{JK}_{(\mathrm{reg})}=\mathbf{b}\left\{\Sigma \mathrm{X}_{1} \mathrm{Y}-\right. \\
\left.\left(\Sigma \mathrm{Y} \Sigma \mathrm{X}_{1} / \mathbf{n}\right)\right\}\end{array}$ & $\begin{array}{c}J \mathrm{~K}_{(\mathrm{reg})}=0,47( \\
835299-5415 \times 5779) / 40)\end{array}$ & 14.40903 \\
\hline 5 & $\mathrm{RJK}_{(\mathrm{reg})}$ & $\begin{array}{c}\mathrm{RJK}_{(\mathrm{reg})}=\mathrm{RJK}_{\text {(reg }} / \mathrm{db}_{\mathrm{reg},} \\
\quad \mathrm{db}_{\mathrm{reg}}=1\end{array}$ & $\mathrm{RJK}_{(\mathrm{reg})}=14.40903 / 1$ & 14.40903 \\
\hline 6 & $\mathrm{JK}_{(s)}$ & 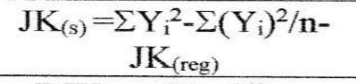 & $\begin{array}{c}\mathrm{JK}_{(\mathrm{s})}=733298-(54157)^{2} / 40- \\
14.40903\end{array}$ & 227.966 \\
\hline 7 & $\mathrm{RJK}_{(\mathrm{s})}$ & $\begin{array}{c}\mathrm{RJK}_{(\mathrm{s})}=\mathrm{JK}_{(\mathrm{s})} / \mathrm{db}_{\mathrm{s}}- \\
\mathrm{db}_{\mathrm{s}}=118\end{array}$ & $\mathrm{RJK}_{(\mathrm{s})}=227.966 / 38$ & 7.402994 \\
\hline 8 & $F_{1 Y \times 1}$ & 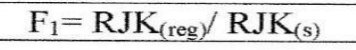 & $F_{1}=14.40903 / 7.402994$ & 1,95 \\
\hline
\end{tabular}

The conclusion is not significant due Fi $<3.92$

Limited funding sources, notwithstanding the condition of local wisdom so the society less attention to work positive sense of temperament with clear reasoning, kind less and can't carry the virtuous soul upright. Although with limited funding sources insignificant budget distribution, so it is not sufficient to fulfill the needs of the facility peralatan.dan supporter neverteless reinforced by local wisdom border management can still be hold out in maintaining the integrity and sovereignty of the country by good.For questionnaire data support the influence of local knowledge on the management of the border can be seen in the analysis of variance (ANOVA) as follows:

Table 4.10 Calculation based on data from ANOVA table research Influence of Local Wisdom on Border Management 


\begin{tabular}{|c|c|c|c|c|}
\hline \multicolumn{2}{|c|}{ Yatas $\mathrm{X}_{2}$} & \multirow{2}{*}{$\begin{array}{c}\text { Pers. Regressi } \\
\text { Rumus }\end{array}$} & \multicolumn{2}{|c|}{$\hat{\mathrm{Y}}=82,144+0,377 \quad \mathrm{X}_{2}$} \\
\hline No & Uraian & & Perhitungan & Hasil \\
\hline 1 & $\mathrm{JK}_{\text {Total }}$ & $\mathrm{JK}_{\text {Total }}=\sum \mathrm{Y}^{2}$ & Data penelitian $\sum Y^{2}$ & 733298 \\
\hline 2 & $\mathrm{JK}_{(\mathrm{a})}$ & $\mathrm{JK}_{(\mathrm{a})}=(\Sigma \mathrm{Y})^{2} / \mathrm{n}$ & $\mathrm{JK}_{(\mathrm{a})}=5415^{2} / 40$ & 733055.6 \\
\hline 3 & $\mathrm{RJK}_{(\mathrm{a})}$ & $R J K_{a}=J K_{(a)} / d_{b}, d b_{a}=1$ & $\mathrm{RJK}_{\mathrm{a}}=733055.6$ & 733055,6 \\
\hline 4 & $\mathrm{JK}_{\text {(reg) }}$ & $\begin{array}{c}\mathrm{JK}_{(\mathrm{reg})}=\mathrm{b}\left\{\Sigma \mathrm{X}_{2} \mathrm{Y}-\right. \\
\left.\left(\Sigma \mathrm{Y} \Sigma \mathrm{X}_{2} / \mathrm{n}\right)\right\}\end{array}$ & $\begin{array}{l}\mathrm{JK}_{(\mathrm{reg})}=0,377(782606- \\
5415 \times 5781 / 40)\end{array}$ & 100.861 \\
\hline 5 & $\mathrm{RJK}_{\text {(reg) }}$ & $\begin{array}{c}\mathrm{RJK}_{\text {(reg) }}=\mathrm{RJK}_{\text {(reg }} / \mathrm{db}_{\text {reg, }} \\
\mathrm{db}_{\text {reg }}=1\end{array}$ & $\mathrm{RJK}_{(\text {reg) }}=100.861 / 1$ & 100.861 \\
\hline 6 & $\mathrm{JK}_{(\mathrm{s})}$ & $\begin{array}{c}J K_{(\mathrm{s})}=\sum \mathrm{Y}_{\mathrm{i}}^{2}-\Sigma\left(\mathrm{Y}_{\mathrm{i}}\right)^{2} / \mathrm{n}- \\
\mathrm{JK}_{(\mathrm{reg})}\end{array}$ & $\begin{array}{c}\mathrm{JK}_{(\mathrm{s})}=2435665-(5415)^{2} / 40- \\
100,861\end{array}$ & 1541,96 \\
\hline 7 & $\mathrm{RJK}_{(\mathrm{s})}$ & $\begin{array}{c}\mathrm{RJK}_{(\mathrm{s})}=\mathrm{JK}_{(\mathrm{s})} / \mathrm{db}_{\mathrm{s}}- \\
\mathrm{db}_{\mathrm{s}}=118\end{array}$ & $\mathrm{RJK}_{(\mathrm{s})}=141.514 / 38$ & 5.527 \\
\hline 8 & $\mathrm{~F}_{1 \mathrm{Yxl}}$ & $\mathrm{F}_{1}=\mathrm{RJK}_{(\mathrm{reg})} / \mathrm{RJK}_{(\mathrm{s})}$ & $F_{1}=100,861 / 5527$ & 18,27 \\
\hline
\end{tabular}

In conclusion the influence of local knowledge on the management of the borders are less significant since $\mathrm{Fi}=18.27>7.84$

Thus the core of step product border management based DEM is the result of the achievement of the management has been able to maintain the sovereignty of the country, though there is still insecurity in the field of security, defense equipment decrease, a lot of lack of facilities, support equipment, coordination is still lacking or out of sync, with a limited budget, and local knowledge help less significant, let alone leadership areas that are not significant, the result is not optimal border management, e. Discussion on Cost / Benefit Research DEM

1. The very lack of border management fees at an angle of expediency for the state and the nation, so the main goal of managers for achieving sovereignty of the nation and the state becomes manifest.

2. The need for the leadership forward in addressing the problems faced by subordinates in order to develop themselves to achieve community development goals Kaltaras to keep local culture in the community development area with resources take advantage natural environment and to people's lives Kaltaras.

DEM research results from step design, installation, process, product and cost can be summarized as follows:

The core of the design steps in border management BPPD DEM is as representative as good managemen BNPP draft the probable, utilizing the available budget with the involvement and empowerment of local communities optimally. The core of the installation steps in the DEM is structuring regularly to border management BPPD as representative BNPP to organize systematically management as well possibly, based on the design of the design is to do the design of the functions of management to carry out the design of planning, design organization, design Mobilization, design coordination, the draft report and budget (budgeting), however most appropriate for border management is POSDCoRB implementation (planning, organizing,staffing, directing, coordinating, reporting and budgeting). 
The core of the process steps in the DEM is implementing border management BPPD as representative BNPP to take real action claiam achieving success border management by POSDCoRB, with the involvement of the military, local government, police, and customs and foster greater public participation in the preservation of nature and the local wisdom and involve relevant stakeholders in helping management border institution. Besides the thing transformational leadership, regional leadership still in its early stages and has not been able realism discourse appropriate with expectations. The core of step cost impack in the DEM is, budget constraints make many sultanate in overcoming the financial to address the vulnerability, buy the proper equipment, and with the lack of teamwork, and leadership of the region has not reached the expected development, especially in Kaltara local wisdom whith less espouse, less integrated with nationl wisdom of the Indonesian nation. This border area management policy should not only approach defence and security alone, but must also pay attention to the specific conditions of the local community as well as the potential of the region, thus the development of the border region security and welfare oriented local wisdom and local culture. Overall results of the study DEM to the design, installation, process, product and cost / benefit of border management can be concluded that the management of the border although limitation budget, but still capable of doing a good job, which is supported by the development team working on a variety of related agencies, though many occur the gap (discrepancy) is striking, particularly security vulnerability can not be resolved, less integrated field personnel, leadership transformational discourse new level, as well as local wisdom has not been able to participate actively sustain take part in border management.

\section{CONCLUSION}

\section{Design, Government Policy border management in the province of North Borneo}

In law which may be applicable in the field borders must have a base that will serve as guidelines officers and border guards to reach purpose of border management, especially in establishing the rule of the Republic of Indonesia in the border region, a draft border management must use management principles POSDCORD particularly in recruitment and human resources quality improvement officers, guards and border management. The local culture and local wisdom should be awakened because it will support the implementation of border management as well as leadership and transformational leadership to application build integration between components official, and border manager.

\section{2. instalation, cooperation in border management strategy in the province of North Borneo}

Need cooperation among officials, border guards and border manager, improve communication and coordination and integration between the operational activities of border services should not walk alone, there should be synchronization and integration. The authority to address problems that occur need to be built SOP and Persistent procedure that are integrated. In improving the capacity and quality at the start with the inter-agency cooperation and training each institution and has established an adequate standard. Joint exercises will increase the quality and capacity of implementing border management and human resources in addition to the development of society need to be a concern, especially in the development of local culture and local wisdom in the Kaltara. 


\section{Process, Strategies Strengthening attitudes behaviors of society and efforts made to achieve sovereignty RI}

The local government as border management need to upgrade development of local culture and the local community local wisdom considering these factors greatly affect the management of border areas such as in Kaltara. The application of customary law needs to be addressed specifically in order not to infringe competence especially in solving the problems in accordance with local rules which protect the rights of the public and society. Directing responsibility and obligation of the society need to continue in order to increase their awareness-raising people in protecting the environment, do not commit criminal acts transactional crime and strengthening local culture and local wisdom. Application of local culture and local wisdom must be in accordance with the contemporary valance contemporary society is needed. The local government should be more concerned in empowering communities to be more involved in the management of natural resources and lives and community empowerment through seat belts. they can help manage the border. security boundary markers through the construction of a parallel road is very appropriate and beneficial addition to maintaining the data which is used to control the border region. In the future government should be able to finance and improve border management, including human resources, the costs required for border management.

4. Products, creation of security in the border region of North Kalimantan Province the central government and local government should be more concerned to address their vulnerability in the security sector in the border region's efforts should be execute to createborder sovereignty of Indonesia. Border security Task Force should be increased its power to reduce the vulnerability of drug trafficking and resolve the border crossing between the occurrence of inter-ethnic fray local and migrant Law enforcement needs to be done indiscriminately. In securing the territorial sea of the Navy needs to conduct a reliable weapon system especially on the ocean detection tool, especially in vulnerable areas in the waters around Ambalat. It is time the central government and the military put in the air skuadron Tarakan air base especially in addressing air reconnaissance conducted by aircraft fuselage Malaysia. Nature creates security in the border region is preferred in the fulfillment company needed TNI personel tried to keep the border region, including weapon system appropriate with the duties and fungtion respectively.

\section{Cost, impact the results of management in the border region North Kalimantan Province}

impacts resulting from the management of the area is still a lot of the crime of smuggling by sea or land which resulted in many people who consume drugs nercotic and deployment throughout the territory of the country. The guidance that are less effective for the community so that future measures need more responsive and aggressive newcomers very negative impact on the unity of the nation. This impact is very detrimental to the life of society, nation and state in the Kalimantan region of the north. lack of public concern is the impact of the lack of empowerment of the government in both the SDA and other empowerment that can improve the livelihoods of communities, including communities in processing belts area a security at the border. The impact of frequent inter-ethnic unrest due to surrouding jealous, the swift entry of drugs through rivers to the village and through the cross-border resulted in many people who consume drugs and the spread of drugs throughout the country.

\section{REFERENCES}

Abidin,Said Zainal. Kebijakan Publik, Jakarta: Suara Bebas, 2005 
Aiken, J. A.Evaluation Review. New York: Mc Graw Hill, 2000

Allen, Louis A. Management \& Organization. New York: McGraw-Hill Book Company, 2003

Amri, Puspa Delima. Pelaksanaan Desentralisasi dan Otonomi di Indonesia, Jakarta: Diklat DepDagri 2000

Amstrong,K. D., dan Richard, D. B. Managing for Performance, NY; Free Press, 2008

Anderson,Benedict. IntroductionCourse Collection.NY: Module, hh.-244, 2003

Andreas, P. and Snyder, T (eds.). The Wall Around the West: State Borders and Immigration Controls in North America and Europe. Lanham, MD: Rowman and Littlefield, 2000

AngeloKenicki., and Robert Kreitner, Organizational Behavior, Boston: Richad D. Irwin, 2008

Argyris,S. J. Strategy Change and Defensive Routines, London: Pitman Publishing, 2010

Arikunto,Suharsimi dan Cepi Safrudin Abdul Evaluasi Program Pendidikan, Pedoman Teoritis bagi Praktisi Pendidikan,Jabar. Jakarta: Bumi Aksara, 2004

Dasar-dasar evaluasi pendidikan, Jakarta, Bumi Aksara, 2000

Prosedur Penelitianf, Jakarta: Bina Aksarai, 2007

Asri, Maria., dan Sulistyobudi,Manajemen sumber daya manusia Jakarta: Bina Aksara, 2006

Bass,Benard M.Leadership and Performance N\Y: Free Press, 2005

Beck,Lynn G., and Joseph Murphy, The Four Imperativesof a Successful. USA: Corwin Press Inc,2006

Beeth,Gunnar. Management in Insidders View, New York: Amacom, 2000

Bennis,Warren.Menjadi Pemimipin dari Para Pemimpin," Rethinking the Future ed. Rowan Gibson, terjemahan Hikmat Kusumaningrat. Jakarta: PT Gramedia, 2005

Bittel, N.K., and R. L, Working Performance,Homewood, Cliffs, New Jersey: Prentice-Hall, Inc., 2004

Blakemore, Kent.Social Policy: An Introduction. Boston: Richard D. Irwin, 2001

Block,James P. Lorin W, Anderson, Mastery learning in classroom instruction, NY: Macmillan, 2005

Bridgman, Peter., Glyn Davis, and Catherine Althaus, The Australian Policy Handbook, Sydney: Allen \& Unwin, 2007

Burns, James M.Leadership. N.Y: Harper and Raw, 2007

Busman,Bridge B. Organization Behavior. Homewood, Cliffs, New Jersey: Prentice-Hall, Inc, 2003

Carley, Michael.Rational techniques in Policy Analysis. London: Heinemann, 2000

Castetter,J.L..Leadership, Englewood Cliff, New Jersey: Prentice-Hall, Inc, 2006

Cokquitt,Jasson A., and A. LePine Organizational Behavior Improving Performance and Commitment in the workplace, Boston: McGraw-Hill-Irwin, 2008.

Compton,Leslie D. Policy and Political federalisme, New York; Free Press, 2004

Courland L. Bovée, Marian Burk Wood, John V. Thill dan George P. Dovel.Management.New York: McGraw-Hill, Inc. 2003.

Cribbin,James F.Leadership Strategies, Englewood Cliffs, New Jersey: Prinyece-Hall, Incp., 2008

Daft,Richard L. Leadership: Theory and Practice. Fort Woth, Texas: The Dryden Press. 2000

Daft,Thomas A. A Theory of Leadership Effectiveness, New York: McGraw Hill Book Company, 2000

Daryanto, Kinerja Organisasi, Jakarta: Bina Aksara, 2008

Deneufville,Judith.Social indicators and public policy; Ineractive process of design and aplliction, Amsterdam: Elsevier scientific Publishing Company, 2005

Dharma, AliKinerja dan Manajemen Sumber Daya Manusia, Jakarta: Erlangga, 2011 
Diknas,Pedoman Evaluasi,Jakarta: Direktorat Ditjen PLS Depdiknas, 2002

Dimock, M.E, G.O. Dimock and L.W. Koenig. Public Administration. New York: Reinhart \& Co., 2001

Donnelly,John P., James L. G., dan John, M. Ivancevic hal. Fundament ofManagement, Homewood, Illinois: Business Publication In., and Irwin, 2007

Douglas, John.Managing a temporary introduction, Englewood, cliffs, New Jersey: Prentice Hall, 2000

Dowell,George P. Management. New York; McGraw-Hill Books Company, 2003

Dunn,William N. Public Policy Analysisi an Introduction, Englewood Cliffs, New Jersye: Prentice Hall, 2001

Dye,Thomas R. Policy Analysis. Alabama: University of Alabama Press, 2006

Eddendy,Rizal. Reinventing Government, Jakarta: Grafindo Utama, 2004

Fayol, H. M. General and Staffing Management.(London: Sir Isaac Pitman \& Sons, LT, 2001

Fitzsimmons,J. A., and Mona J. F. Service Management: Operations,Strategy, and Information Technology, Boston: McGraw-Hill, Inc, 2007

Gardner,John W. On Leadership, (New York: The Free Press A Diviision of Macmilan, Inc., 2008.

Gardner,Terry W. Leadership Authentic. New York: McGraw-Hall Books Company,2008

Garvin,David A. Service Quality Management, New York: McGraw-Hill Books Co, 2003

Geertz, H.Aneka Budaya dan Komunitas di Indonesia. Jakarta: Yayasan Ilmu-Ilmu Sosial, 2001

Gibson,James L., John M. Ivancevich dan James H. Donnelly, Jr. Organizations Behavior - Structure Process. Homewood, Boston: Richard D. Irwin,2001

---------,John M. L., John M. Ivancevic hal., dan James P. D. Organizations: Structure, Process, Behavior. Texas: Business Publications, 2003.

Giroux,P. A.Border Crossings, Cultural Workers and the Politics of Education, Great Britain: Routledge. 2005

Goatz, T. J., and L.M LaComte, Teacher and Proffession. NJ: Free Press, 2010

Gomes,Karl L. Standard Performance, Texas: Business Publications Inc., 2006

Gordon, Lindon F.Management. New Delhi: McGraw-Hill International, 2003.

Grant,Thomas A. Product Service Management, USA: American Management Association, Inc, 2003.

Gray,Richard M., John F. Smeltzer Economic Plan, NY: McGraw-Hill, Books Company, 2010

Gredler,Margaret E. Bel. Learning and Instruction. New York: Macmilland Publishing Company, 2001.

Grotius, Hugo.De iure belli ac Pacis.Paris: Janssonio-Waesbergios, 2004

Gunawan, Psiklogi kerja, Semarang: Pandanaran, 2005

Guo, R. Cross Border Resource Management, Theory and Practice. Amsterdam: Elsevier, 2005

Guthrie, Jane P.School and School Productivity: Boston: Richard D. Irwin, 2004

Hale,Mery J.. Organization Theory, Modern, Symbolic, and Postmodern Perspectives New York: Oxford University Press, 2004

Hall, Share.Promoting Elegance in Policy Theory and process Evaluatio: Simplifying Arenas of Power, Berkeley: University of California Press, 2005

Hampton,David R. Management.New York: McGraw-Hill Book Company, 2008

Hatch,Mary Jo. Organization Theory, Modern, Symbolic, and Postmodern Perspectives. New York: Oxford University Press.2007.

Hersey, Paul.Management of Organizational Beharvior New Jersey: Prentice hall, inc, 2006 
Hingley,W. dan Frank Osborn. Financial Management Made Sample. London: Publishers W. P. Allen \& Company Ltd., 2007

Holand, F.T. Management Project Budgeting NY; Prentice Hall, 2012

Horton, Paul B. Sosiologi.Jakarta:Erlangga, 2007.

Hunt,John W. Managing People at Work: A manager'sGuide to Behaviour in Organization. London: McGraw-Hill, Inc, 2002.

Isjwara, F.Pengantar Ilmu Politik. Bandung: Binacipta. 2002

Jenkins, William.Policy Analysis: A Political and Organizational Perspective, London: Martin Robertson, 2008

Johnson, L. K., and Luecke, R.The Essential of Managing Change and Transitions. Boston, Massachusetts: Harvard Business Press, 2005

Karlof,Bengt dan Svante Ostblom, Benchmarking: A Signpost to Excellence in Quality and Productivity. London: John Wiley \& Sons, Ltd, 2004

Kartoditjo,Sartono. Negara dan nasionalisme Indonesia, Yogyakarta: PT Gramedia Widiasarana Indonesia, 1995

Kartono, Kartini. Pemimpin dan Kepemimpinan.Jakarta: Rajawali, 2003

Koentjaraninggrat. 2009. Ilmu Antropologi. Jakarta: Renaka Cipta., 2009

, Kebudayaan Metalitas dan Pembangunan. Jakarta: Penerbit PT. Gramedi, 1987

Koontz, H. O' Donnel, Principles of Management :Analysis of Management Functions. Twowenty Fourth Edition. N.Y: McGraw-Hill Books Company, 2000

Konopaske,Robert and Richard D. Matheson, Global Management and organizational Behavior,NY. McGraw-Hill, International, 2009

Koontz,Harold dan Cyril O'Donnell, Essentials of Management. New Delhi: Tata McGraw-Hill Publishing Company LTD., 1981

Krone,Robert M. Systems Analysis and Policy sciences: Theory and Practice, New York: John Wiley and Sons, 2000

Lascar, D.Stability in model theory, NY: Wiley and sons, 1987

Leslie,Rue, and John Holand, Leadership Strategy, Homewood, Boston: Richard D. Irwin, Inc. 2001

Lewis,Ralph G. dan Douglas P Smith, Total Quality in Higher Educational. Delray Beach, Florida: St. Lucie Press, 1994

Lincoln, Y., and G. Guba, Naturalistic Inquiry, Beverly Hill, Sage Publication, 2000

Locke. E. A., and Gery P. L. Theory of goal setting and Task Performance, NJ: Prentice Hall, Inc., 2010

Lowi,Theodore J. The State in Politics;Regulatory Policy and the social Sciences. Berkeley: University of California Press.2005

Loundrouf, Henry. Management Repotin, London: Longman, 2011

Luis, R. K. Centralizagtin and decentralization, London; Longman, 2001

Mejia Gomez anfRobert L. Cardy Management: People, Performance, Change, 3rd edition. New York; McGraw-Hil 2008

Mabry, L, and R.E. Stake, Evaluation in the Post-Modern Dilemma. New York: Jai Press, Inc, 2000

Mangkunegara,Anwar Prabu evaluasi kerja SDM. Bandung: PT. Refika Aditama, 2005

Massie,Joseph L., dan John Douglas, Managing: A Contemporary Introduction Englewood, Cliffs, New Jersy: Prentice Hall, Inc, 1977 
Matthew,Arnold. Culture and Anarchy New York: Macmillan, 2000

Mayer,Robert R., dan Ernest Greenwood,Public Policy, Terjemahan Sutan Zanti Arbi dan Wayan Ardana, Jakarta: Rineka Cipta

McLaughlin, M. W., and D.C. Phillips, Evaluation and education: at quarter century. Chicago: National Society for the Study of Education, 2000

McLeod, William T. The New Collins International Dictionery of The English Language Singapore: Graham Brash (Pte) Ltd., 1983.

McRaé and Duncan J.R, Public Policy and Decision making, New York: McGraw-Hill Books Company, 2003

Mendelhall, Mark., Bey Jane Punnet and David Ricks, Global Management; Leadership Roller, American Journal, Education Survey Association, is: 310932 v 102, Fall 2000

Meyer, R.D.Worker and psychologis.HEC Montréal University Press, 2002.

Moitarani,AlanManajemen Sumber daya Manusia Berdasarkan Kompetensi Jakarta: Pustaka Utama Grafika, 2005

Moleong, Lexy. Metode Penelitian Kualitatif, Jakarta: C.V. Radja Wali, 2007

Muhibah Kepemimpinani Jakarta; Bina Aksara, 2001

Mulyono, Metode Penelitian Kualitatif, Bandung: Alfa Beta, 2009

Murphy,Glan F., and J.F. Forland, Policy Theory and Practice, McGraw-Hill Books Company, 2000

Nadle, David.The NOW Employee. Houston, Texas: Gulf Publishing Company, 1991

Ndraha, Taliziduhu.Budaya organisasi, Jakarta, Bina Aksara, 2000

Nawawi, Hadari. 2001. Organisasi Sekolah dan Pengelolaan Kelas.Jakarta: CV. Haji Masagung. 2001

Nikijuluw,Tom, K. Organization Theory and Practice, Boston: Richard D. Irwin, 2003

O’Leary, Elizabeth, Kepemimpinan. Edisi Pertama. Yogyakarta: Andi, 2001

Olivier, Vonk. Dual Nationality in the European. London: Martinus Nijhoff Publishers. 2002

Paton,Carl V. and David S. Sawicki, Basic Methods of Policy Analysis and Planning, Englewood Cliffs, New Jersey: Prentice Hall, 2001

-,Denis G.Sampling Metode London: Longman, 2002

Pindur, W. Rogers, and P.S. Kim, The history of management: a global perspective. NY: Free Pess, 2004

Purwanto,M.Ngalim Administrasi dan supervisi pendidikan. Bandung,Remaja Rosda Karya, 2005

Riberu, J. Dasar-Dasar Kepemimpinan. Jakarta: Pedoman Ilmu Jaya, 2003.

Ritzer, George. Teori Sosiologi. Yogyakarta: Pustaka Belajar, 2012

Rivai,Vetihzal dan Dato' Ahmad Fauzi Muhammad Basri, performance appraisal. Jakarta: PT. Raja Grafindo Persada, 2005

Robbins,Stephen P. Essential of OrgaizationalBehavior. Englewood Cliffs, New Jersey: Prentice Hall inc 2004 Jakarta: Arcan, 2007 hall, inc, 2006

Rousseau,Jean Jacques.Du Contrat Social Ou Principes Du Droit Politique cetakan 123 Paris: Janssonio-Waesbergios, 2000 
Rumford, C. 'Borders and bordering', in G. Delanty (ed.) Europe and AsiaBeyond East and West: Towards a New Cosmopolitanism. London: Routledge, 2006

Safarudin,Moc P., dan Yusuf Nasution, Kepemimpinan masa depan, Jakarta: Balai Pustaka, 2006

Salam,Suprayogi. Peran Manajemen dalam organisasi, Surabaya: Surya Press, 2009

Saydam, Gouzali.Manajemen Sumber Daya Manusia.Suatu Pendekatan Mikro. Jakarta, Kresna Prima Persada, 2005

Sagara, Syaiful. Manajemen Berbasis Sekolah dan Masyarakat.Jakarta : PT. Nimas Multima, 2004

Shallice,T. Specific planning and Organizing of Management. (London Royal Society, 2002

Soewarno Handayani, Soewarno. Pengantar Studi Ilmu Administrasi dan Managemen. Jakarta: PT. Gunung Agung, 2005

Sayuti,Nurhamid. Diktat Manajemen pendidikan, Jakarta,.UHAMKA, 2005

Schein,Edgar P. Organizational Culture and Leadershihal. San Fransisco: Josey-Bass Publishers, 2002

SchneierBruce Beyond Fear: Thinking about Security in an Uncertain World, NY: Copernicus Books, 2000

Schroe,P. J. Van Der., dan Willem P. Makaliwe, Manajemen dan Organisasi Perusahaan. Jakarta: Ghalia Indonesia, Balai Aksara dan Yudhistira, 2002

Scriven. Evaluation and Action, interview with Expert Evaluation, New York: SAGE Publication, 2009

Siagian,S.P. Manajemen Sumber Daya Manusia, Jakarta; Ghalia, 2003

---------. Pengambilan Keputusan. Jakarta: Gunung Agung

Sianipar, Mardi.Menuju Organisasi pelayanan publik / organisasi Pemda Nasional yang Relevan dan Bermutu, Jakarta: Balai Pustaka, 2008

Siegel,Laurence dan Irving, M. Lane, Personnel and Organizational Pshycology. Illinois: Richard D. Irwin, Inc. 2007.

Simon,A. AdmiInistartion and Performance, NY: MacGraw-Hill Book Company, 2004

Soeharto, Edi. Kebijakan, Jakarta: Grafindo Utama, 2000

Soekanto,Suryono.Pengantar Sosiologi, Jakarta: Rajawali, 2005

Soetjipto dan Raflis K.Profesi Keguruan, Jakarta : Ditjen Dikti, depdikbud, 2003

Spradley,John S.Data complalation for Research. NJ; MacGraw-Hill, Book Company, Ltd, 2000

SteersRichard M., Lyman W. Porter dan Gregory A. Bigley, Mativation and Leadership at Work. New York: McGraw-Hill Companies, 1996.

Stuffebeam,D.L., and Chris L.S. Coryn. Evaluation Based, Leadership School Administration in Contemporary Persprctive. New York: State University of New York

----------------. Evaluation Models: Viewpoints on Educational and Human Services Evaluation, Kluwer Academic Publisher, Massachusetts, 2000

Sudaryono, Leaderdhip teoridan praktek kepemimpinan Jakarta: Lentera Ilmu Cendikia, 2014

Sudjana, Evaluasi Program, Jarata: Bumi Aksara, 2006

Sugiyono, Uji reliabilitas dengan uji Cronbach. Bandung :Alfa Beta, 2007

Sulistyo, Hilmawan Otonomi dan pembangunan SDM daerah, Jakarta; Rineka Cipta, 2002

Syam,Mardjin. Kepemimpinan Dalam Organisasi, Surabaya: Yayasan Pendidikan Practise, 2006

Tank, Grnd Rod.Management and Excecutive Manager. Illinois: Richard D Irwin, Inc. 2004. 
Terencce,Michell R. The People Organizations: An Intruduction to Organizational Behavior, New York: McGraw-Hill Book Company, 2003

Thoha, Mitfah.Perilaku Organisasi, Konsep dan Aplikasi, Jakarta: PT. Radjawali, 2003

Tiffin, J., dan J/ Mc. Ernest Industrial Psychology, Tokyo: Maruzen Co., Ltd., 2005

Tillman, Robert D. Management Practice, New York: Macmilan, 2000

Tim Dosen UPI, AdmInistrasi Pendididkan. Bandung: UPI Press, 2002

Timpe, A. Dale.Seri Manajemen Sumber Daya Manusia. Kepemimpinan. Leadership, Jakarta, Elex Media Komputindo, 2000

------------------. Seni Kepemimpinan. Jakarta: Bina Aksara, 2995

Uichol, Kim.Culture, science and indigenous psychologies: An integrated analysis., Handbook of culture and psychology. Oxford: Oxford University Press, 2001

UNESCO.Universal Declaration on Culture, Issued on International Mother Day.New York: 2002

Vendung, Evert. Public Policy and Program Evaluation, New Jersey: Trncsaction Publiser, 2009

Verdeber,R. F. Communicate! Bellmont, California: Wadsworth, Inc., 2007

Viviane, F. et G.B. Gilbert, Les Strategies d'apprentissage, Paris, CLE International.De Landsheere, Définir les objectifs de l'éducation, Paris, PUF, 2000

Vondle,D. P.Service Management Systems, New York: mcgraw Hill Publishing Company, 2008

Vora,D. O.OrganizationCommunication, New York: John Wiley and Sons, 2002

Weiner, N. K.Communication Attraction. New York: McGraw-Hill, Inc., 2004

Wellington, P.Kaizen Strategies for Customer Care, terjemahan Alexander Sindoro, Batam: Interaksara, 2008

West,G.W., and Holand F. L. Strategic Planning, New York: McGraw-Hill Book Company, Inc, 2009

White, L. The Science of Culture: A study of man and civilization. New York: Farrar, Straus and Giroux, 2009

Whyte, Martin King.BonderyTeritory area and community life, California: University of California Press, 2003

Wildschut,Richard T. Qualitative Research, Englewood.Cliffs. New Jersey: Prentice Hall, 2014

Wiles,Kimball R. Supervision for Better Schools. Englewood Cliff, New Jersey: Prentice-Hall, Inc., 2001.

Winardi, J.Azas-azas Manajemen. Bandung: Penerbit Alumni,2002

Wirawan, Profesi dan Standar Evaluasi. Jakarta: YBI, Uhamka press, 2004

. Kepemimpinan teori dan praktek untuk penelitian, Jakarta: Uhamka Press dan Yayasan Bangun Persada, 2003

Withmore, John. Choacing for performance London; Nicholas Brealey publishing, 2005

Wolf, Robert. Definitions of Policy Analysis, London: Martin Robertson, 2003

Yamit, Julian..Manajemen kualitas produk dan jasa. Yogjakarta; Ekonisia, 2005

Yulk, Gary.Kepemimpinan Dalam Organisasi. Jakrta: Penerbit Indeks, 2005.

\section{Wib Site.}

Albab, Ulul.Inside And Outside Government (Aktor Kebijakan Publik) Diakses dari situs Jakarta, http://ulul@unitomo.ac.id, 2005 
http://nasional.kompas.com/read/2014/11/27/02253741/Polisi.Akui.Kesulitan.Jaga.Wilaya

hal.Perbatasan.Indonesia , diakses pada 7 Juli 2015

https://www.pu.go.id/isustrategis/view/28, diakses tanggal 8 Juni 2015

Jati,Wasisto Raharjo. Pembangunan Gerus Kearifan Lokal, dalam Kompas, 20 April 2011, Jakarta, yang diakses 11 April, 2016.

Provinsi Gelar Pilkada, Desember 2015 Tempo.co.Tanggal 18 Maret 2015.Dan diakses tanggal 24 November 2015.

Yuanita,Elina. Evaluasi Model Countenance Stake.elinayuanita.blogspot.com/.../model-coun... 3 Jan 2013 (diakses tgl 19 Juni 2014

\section{Journal}

Aelenei, V. Dreptul frontierei de stat, Bucharest: vol. I, Pro Transilvania Publishing House, 2001

Brunner,James L. Organization Construction; Leadership School Organzation.American Journal, Education Survey Association, is: 310932 v 89 Iss: (1) March 2007

- N. N. Evaluasi Kurikulum Model Countenance stake. Hakekat pendidikan.blogspot.com/.../eval...20 okt 2011 diakses tgl 17 Juni 2014

Deslandes, G. Management in Xenophon's Philosophy : a Retrospective Analysis, Journal Chicago, USA Annual Research Conference, Philosophy of Management, 2014, July

Singh,D. J. dan Bob D. B. School Management: Environment Climate, Education Chula Vista, Calif) v 116 Spring, 2006

Swandari, Fifi 2003. “Menjadi Perusahaan yang Survive Dengan Transformasional Leadership” Jurnal Ekonomi, Manajemen dan Akuntansi vol.1 No.2 Mei 2003

Tufo, Sarah Del.Trust Evaluation; Washington, DC, Journal of Global Evaluation Office,Xi -v 785.5634, 2000

Urwick,. Organization as a Planning Technical Problem..New York:Journal Institute of Public Administration, 2010, July 